\title{
Lake States Natural Resource Managers' Perspectives on Forest Land Parcelization and Its Implications for Public Land Management
}

\begin{abstract}
Field-based public natural resource managers in the Lake States (MI, MN, WI) were surveyed for their perspectives on various aspects of private forest land parcelization. This includes their perceptions of recent changes in parcelization activity, drivers and impacts, mitigation strategies, and ability to influence parcelization. Their perspectives on the implications private forest land parcelization has on public land management were also sought. Across the Lake States, most public natural resource managers have witnessed an increasing frequency of forest land parcelization. They consider development potential and proximity to population centers to be the most influential driver of parcelization, with decreased timber supply and loss of recreational access on private land the most likely outcomes. The study documented important perceived linkages between private forest land parcelization and public land management, such as increased conflicts on public land, decreased access to public land, and increased demand for and cost of managing public land.

KEYWORDS: public forest land management, private forest land ownership, subdivision, parcellation, fragmentation
\end{abstract}




\section{INTRODUCTION}

Forest land parcelization, defined as the fragmentation of forest land into smaller ownership blocks, has been identified as an important concern in many forested areas of the United States and abroad (e.g., Mundell et al. 2010, Butler and Ma 2011, Haines et al. 2011, Xie et al. 2014). The National Association of State Foresters, whose members are the lead state agencies in the United States responsible for administering private forest landowner assistance programs, considers parcelization to be an impediment to forest health and sustainability (National Association of State Foresters 2015). In its position statement on the loss of private forest land in the United States, the Society of American Foresters acknowledges the adverse impact private forest land parcelization can have on forest goods and services (Society of American Foresters 2015). Beyond the United States, studies have documented parcelization as an important issue affecting private forests in many other parts of the world (e.g., Harrison et al. 2002, Leppanen 2008).

The extent to which private forest land in the U.S. has been subdivided is considerable. Data from the National Woodland Owner Survey indicates that in 2006, owners of nearly 6 million acres of family forest land in the United States planned to subdivide some or all of their forest land in the next five years (Butler 2008). Parcelization has been shown to be associated with the loss of wildlife habitat, timber availability, diminished water quality, and greater restrictions on recreational access (Mehmood and Zhang 2001, Rickenbach and Gobster 2003, Gobster and Rickenbach 2004, LaPierre and Germain 2005, King and Butler 2005). It has also been described as a potential forerunner to forest fragmentation and development (Mundell et al. 2010).

Numerous studies have examined the factors driving private forest land holdings to be subdivided into smaller ownership blocks, as well as how this phenomenon impacts the ability of forests to provide important economic, ecological, and social benefits (see Hatcher Jr. et al. 2013 for a recent review). Many of these studies used landscape change models to classify and characterize parcelization drivers 
and/or effects (e.g., Mehmood and Zhang 2001, Gustafson and Loehle 2006). Others have incorporated biophysical data to evaluate parcelization effects on forest health and productivity (e.g., Germain et al. 2007). Still other studies have surveyed forest landowners or loggers for their opinions about the causes and effects of parcelization (e.g., Kittredge et al. 1996, Moldenhauer and Bolding 2009, Sanborn-Stone and Tyrrell 2012).

Natural resource professionals (e.g., foresters, wildlife managers) working in predominantly forested landscapes are a potentially rich source of information on forest parcelization drivers, impacts, and trends. This group is likely to have an in-depth, on-the-ground understanding of the extent, condition, and uses of the forests in their area; importance of these forests to the regional economy; patterns of forest ownership (both public and private); and important threats to the health and productivity of these forests. As such, we suggest they have unique, field-based perspectives and insights on aspects of forest land parcelization that can be important to researchers and policy-makers. Additionally, while parcelization is often viewed as largely a private forest land issue (i.e., the result of a landowner decision affecting private land), we argue that this phenomenon can have significant implications for public lands. In this regard, public natural resource managers can offer distinct perspectives on how private forest land parcelization activity is or may affect the management, use, and protection of public forest lands.

However, natural resource managers have been largely overlooked as a potential source of information on private forest land parcelization activity and its effects on public lands. To our knowledge, only a few studies have examined the perspectives and knowledge of natural resource professionals regarding drivers and outcomes of forest parcelization. Gobster and Rickenbach (2004) and Rickenbach and Gobster (2003) identified perceived patterns, drivers, and outcomes of forest parcelization in northern Wisconsin among public land managers, conservation and environmental organizations, and resourceoriented stakeholders. They found that parcelization is creating new ownership patterns across the 
landscape, most of which are viewed as negatively impacting recreation opportunities, forest health, timber-based economies, and local communities. Knoot et al. (2009) conducted interviews with natural resource managers to identify factors, including forest land parcelization, that impact oak regeneration, finding that changing ownership patterns, along with other factors, are limiting oak regeneration.

Our work adds to the literature in two distinct ways. First, we provide a regional focus of how public natural resource professionals working in a range of resource management disciplines perceive forest parcelization as an issue within their work area. We also describe their perspectives on important drivers and consequences, as well as perspectives on the effectiveness of alternative strategies to deal with parcelization impacts. Most parcelization studies to date have attempted to document the process and drivers of parcelization, not what natural resource managers are actually observing in the field or their views on parcelization. Such observations derived from on-the-ground, localized knowledge can help confirm/refute hypotheses or findings from other parcelization studies, as well as provide an important perspective on the effectiveness of policies, programs and tools for stemming the incidents or impacts of parcelization.

Second, we describe the perspectives of public natural resource managers regarding the implications of private forest land parcelization on public land management. Gobster and Rickenbach (2004) documented stakeholder beliefs that the loss of private land access resulting from parcelization has increased recreational pressure on public lands, but beyond their work this topic has not been explored in the literature to any degree. Field-based public land managers are on the frontlines of this phenomenon, and have valuable first-hand knowledge of parcelization's spill-over effects on public lands. Surveying public resource managers allowed us to begin to explore the relationship between private land parcelization and its perceived impacts on public forest land management. Our hypothesis is that private forest land parcelization is adversely impacting public land management. 


\section{DATA AND METHODS}

A questionnaire was developed to obtain information from field-based natural resource professionals on multiple aspects of forest land parcelization. Survey questions and potential response categories came from three principal sources: a review of the parcelization literature, our previous work on forest land parcelization, and perspectives and feedback from natural resource professionals at an interactive scoping session on forest land parcelization that we conducted at a conference for public natural resource field professionals in Minnesota in 2012.

The survey included questions regarding the respondent's familiarity with parcelization, observations of parcelization trends in their work area, perspectives on important drivers of parcelization and potential outcomes associated with a parcelized landscape, strategies for preventing or slowing the rate of parcelization, and respondent background information. Modified Likert scale response items were provided for these questions. The questionnaire also provided an opportunity for respondents to provide open-ended comments on various aspects of forest land parcelization.

An on-line version of the draft questionnaire was developed using SurveyMonkey's Wufoo on-line Form Creator (www.wufoo.com). Once created and tested for functionality, the on-line questionnaire was pre-tested with three public natural resource professionals. Survey pre-testers were asked to provide feedback on both the content and format of the questionnaire, specifically its readability and completeness, the appropriateness of response categories provided, and its overall length. A final version of the questionnaire was prepared based on the feedback provided from the pre-test. The questionnaire was subsequently reviewed and approved by the University of Minnesota's Institutional Review Board (IRB).

The survey's target population was field-based public natural resource managers in the Lake States (MI, MN, WI). This region was chosen because its forests are a pervasive land cover, support a diverse forest products industry, and are located in amenity-rich areas (e.g., lakes and rivers) that are 
attractive for recreation and second-home development. This is also an area where forest land parcelization has been documented to be occurring (e.g., Gobster and Rickenbach 2004, Mundell et al. 2010, Kilgore et al. 2013).

Survey recipients consisted of forestry, wildlife, and related conservation professionals (identified by their position titles) working for federal (i.e., USDA-Forest Service and Natural Resource Conservation Service, USDI-Fish and Wildlife Service), state (i.e., state departments of natural resources), and county/local (i.e., county land departments, soil and water conservation districts) agencies. They included field-based individuals with titles such as field forester, district wildlife manager, recreational planner, and soil conservationist. ${ }^{1}$ We did not survey private sector natural resource managers, as a primary focus of our research was better understanding the impact parcelization has on public land management.

Forest cover maps of each state were used to identify the predominantly forested areas in the region. ${ }^{2}$ E-mail addresses for individuals working in the forested regions of each state were obtained by searching agency websites and contacting agency information officers. The final survey mailing list consisted of 773 e-mail addresses and represents, to the best of our knowledge, a census of public agency natural resource field professionals (as we defined them) working in the forested landscapes of the Lake States.

The internet survey was administered in fall 2014 following a modified Dillman approach (Dillman et al. 2009). Survey administration consisted of a pre-survey e-mail to public agency administrators (e.g., division directors) describing the study and informing them that a questionnaire would be sent to their field-based employees within the next week; a pre-survey e-mail to survey recipients describing

\footnotetext{
${ }^{1}$ Our intent was to survey field-based natural resource professionals. Given that we were selecting survey participants from websites and agency email lists based on their title, it is possible that some people in this category could have been omitted and/or some people included may not have actually been in field positions.

${ }^{2}$ Predominantly forested areas were defined as areas where at least half of the terrestrial land cover is forested.
} 
the study and indicating they would be receiving an on-line questionnaire within the next few days; an email to survey recipients with a link to the on-line questionnaire; and two follow-up reminder e-mails sent one and two weeks after the initial survey invitation, respectively.

The survey produced 275 usable responses for a $36 \%$ response rate. Table 1 contains the breakdown of survey recipients and usable responses by state and unit of government. Table 2 indicates the primary professional discipline of the survey respondents by state. Non-response checks were performed in two ways. Early and late survey responders (i.e., the first and last $20 \%$ of respondents) were compared using chi square tests for differences with respect to their familiarity with parcelization, perception of the degree to which parcelization is an issue in their region, and perception on the degree to which parcelization is occurring. Early and late responders are not significantly different in these three areas $(\alpha=0.05)$. We also examined whether respondents disproportionately represent a state, discipline, or unit of government (i.e., county, state, federal) relative to the survey population. Respondents are representative of the survey population with respect to their state, governmental unit, and the forestry and wildlife disciplines $(\alpha=0.05)$. However, soil and water conservation professionals are under-represented (e.g., $14 \%$ of respondents versus $25 \%$ of survey recipients) and recreation/planning professionals are over-represented in the survey (e.g., $9 \%$ of respondents versus $4 \%$ of survey recipients).

Kolmogorov-Smirnov tests indicated that our response data do not follow a normal distribution, and that non-parametric summary statistics and tests are appropriate. Kruskal-Wallis and Dunn's post-hoc tests were used to identify significant differences in some of the modified Likert-scale response data among respondent groupings (e.g., by state). Data analysis was performed using IBM SPSS Statistics, Release 21.

The open-ended comments provided by natural resource managers are presented to aid in further interpreting and contextualizing the quantitative response data. This was accomplished by two 
researchers independently reading each comment and assigning it a code that categorized its content and focus. Once completed, the researchers jointly reviewed the coding assignments for consistency and accuracy. Comments were subsequently reread and, where needed, recoded. Once the coding process was complete, comments were organized and analyzed according to major themes.

\section{RESULTS}

\subsection{Parcelization Familiarity and Concern}

Most individuals indicated they are quite familiar with forest land parcelization as a concept (Table 3). Across the Lake States region, the median score among survey respondents is 4 on a five-point scale (with a 5 being 'very familiar'). Nearly half (44\%) consider themselves to be very familiar with forest land parcelization. Only 4\% stated they are not familiar with the concept. Familiarity with forest land parcelization was found to be associated with the level of government the respondent worked for $\left(\chi^{2}=\right.$ 23.51, $p<0.001)$. Natural resource managers working for federal agencies are less familiar with the concept of forest land parcelization than those working for state or county/local land management organizations $(p \leq 0.001)$. Foresters are significantly more familiar with the parcelization than soil and water conservation professionals $\left(\chi^{2}=15.89, p<0.001\right)$. Yet, no differences were found in respondent familiarity with forest land parcelization based on the state they work in $\left(\chi^{2}=0.895, p=\right.$ $0.639)$.

Respondents believe parcelization is an important concern affecting forests and the benefits they provide (Table 4). The median score for individual states and across the region is 4 on a 5-point scale ( $5=$ important concern, $1=$ not a concern $)$. Across the region, over $80 \%$ of the respondents rate their concern about forest land parcelization as 4 or 5, with $39 \%$ giving it the highest rating of concern possible. Only seven individuals feel parcelization is not or minimally a concern (i.e., rated their 
concern a 1 or 2). No differences in the concern over forest parcelization are associated with the level of government $\left(\chi^{2}=3.267, p=0.195\right)$, professional discipline $\left(\chi^{2}=0.515, p=0.916\right)$, or state the respondent works in $\left(\mathcal{X}^{2}=0.738, p=0.691\right)$. Stated differently, the region's field-based natural resource managers broadly consider private forest land parcelization to be an important concern in the region.

When asked to characterize the degree to which they think their employer (i.e., organized by unit of government) considers forest land parcelization to be an important concern, the responses are less emphatic than their own concern (Table 5). The median score across all respondents is 3 on the same 5 -point scale $(5=$ important concern, $1=$ not a concern $)$. Only $16 \%$ believe their employer considers forest land parcelization to be an important concern, and $8 \%$ feel the agency they work for does not consider parcelization to be a concern. Natural resource professionals working for state agencies rate their agency's concern for forest parcelization higher than those respondents working for federal agencies $\left(\boldsymbol{X}^{2}=25.54, p<0.001\right)$.

\subsection{Perceived Changes in Parcelization Activity}

Respondents were asked to characterize the rate of forest land parcelization activity in the geographic area they work in over the past 10 years (Table 6). Region-wide, over $80 \%$ of respondents indicate there has been an increase in parcelization, with $25 \%$ stating the increase has been substantial over that period. Less than $4 \%$ describe a decreasing trend in forest parcelization. Natural resource manager's characterizations of changes in the rate of parcelization differ significantly across states $\left(\mathcal{X}^{2}=7.87, p=\right.$ 0.02). Survey respondents working in Wisconsin perceive forest land being parcelized at a greater rate over the past ten years than do Michigan respondents.

Several comments were offered by respondents characterizing their perspectives on parcelization activity in their area. As expected, many describe forest ownership patterns that are highly 
fragmented. Some provided additional detail on the incidence of and trends in parcelization activity.

For example, one respondent offered the following,

"Parcelization is occurring within the primary corporate industrial forest holdings in the state ([Upper Peninsula]-my work area) amongst various industrial and [timber investment management organization] landholders, then progressing down to initial private individual land holdings."

Others provide important context with respect to where on the landscape forest parcelization is most prevalent.

\footnotetext{
"The issue seems to be worst in areas near the smaller villages and in areas where there is more water access."

“As it stands, it's obvious that parcelization is growing around city centers, lakes, streams and road access ways."
}

Yet a few respondents state that forest land parcelization is not a major issue in their work area.

"I am located in northeastern MN, so parcelization is not one of the biggest concerns we have. Our area, over $85 \%$ of land is publically owned, with the surrounding counties being about the same."

“The area is economically depressed, with human population dwindling with each passing year. Thus, there is little demand for second homes or recreational properties. Overall, there has been less demand for real estate here than other places in the Great Lakes region, and that will probably continue to be the case going forward...we are too far from major population centers to be attractive as second homes. Therefore, parcelization is not a huge issue here at this time." 


\subsection{Parcelization Drivers}

A number of factors have been identified in the literature as potential drivers of forest land parcelization (see Mehmood and Zhang (2001) and Gobster and Rickenbach (2004) for examples). We asked respondents for their opinions on how they think many of these factors may be related to or driving private forest land parcelization (Table 7). Respondents rated these factors on a 5-point scale (5=very influential, $1=$ not influential). Forest land with high development potential is considered to be the most influential driver of parcelization, with parcel proximity to population centers, parcelspecific features, and forest land prices as the second, third, and fourth most influential factors, respectively. Other factors with median scores higher than the midpoint value (3) are land prices, intergenerational ownership transfer, and property taxes. The two forest management-related factors that were evaluated, stumpage prices and the amount of timber harvesting activity, are considered the two least influential parcelization drivers.

Many survey respondents provided additional comments and perspectives on what they believe is driving parcelization. In general, these drivers can be characterized as economic, familial, recreational, and cultural. Economic drivers are strongly tied to the value premium associated with small tracts of forest land, relative to the price of large acreage parcels. Kilgore and Mackay (2007) refer to this phenomenon as the "retail to wholesale discount" whereby small acreage tracts sell for substantially more than larger tracts with similar characteristics. This point is accentuated by the following comments.

“As long as a 40 will sell for $\$ 5,000 /$ ac and a 320 will sell for $\$ 3,000 / a c$, parcelization will occur."

"Private landowners with the best of intentions on keeping the property together lose sight of the goal when realtors start flashing large dollar signs." 
Several respondents mentioned intergenerational transfer of forest land as a major driver of parcelization. For example,

"The main factors (in my opinion) are mom and pop dividing the land to the kids..."

The strong demand for recreational property, primarily for hunting, was also cited frequently as a reason for forest land parcelization. Comments supportive of this sentiment include,

"Unquestionably whitetail deer and deer hunting has driven our land prices and parcelization patterns."

"The buyers are mostly using the land for hunting and recreation..."

The cultural factor offered by several natural resource managers as an important driver of parcelization is simply the desire for individuals to have a place to escape to. The following comments typify this sentiment.

\footnotetext{
"The biggest driver of parcelization is people wanting to own their own piece of land where no one can tell them what to do."

"Everyone wants their own little piece of paradise, so to be able to afford it they are buying smaller parcels."
}

\subsection{Parcelization Outcomes}

Natural resource managers were asked to evaluate the likelihood of several potential outcomes occurring as a result of forest land parcelization (Table 8). Three of these potential outcomes (increased land development, decreased timber supply, loss of recreational access on private land) have median values of five on a 5-point scale ( 5 = very likely to occur, $1=$ not likely to occur). Respondents indicate that the loss of private forest land is the least likely outcome of those parcelization outcomes evaluated. 
Questions related to parcelization outcomes generated the most comments from respondents. In general, these comments convey four themes regarding the impacts associated with forest land parcelization. The first is how parcelization constrains the public's access to forest land (both public and private) for recreational purposes. Several commented on how fragmenting private forest land ownership into smaller blocks can sometimes landlock the surrounding public forest land such that access is prohibited.

"Due to the large public land base, these land sales have little effect on the overall timber and wildlife management activities. However, these isolated parcels often control the best access into larger blocks of public land."

"Even though there are vast areas of continuous public lands, surrounding parcelization has an impact if private owners will not allow access through these lands."

"If the tiny blocks are on the road frontage and they block access to the big block behind, that could be the worst."

Others commented on how parcelization makes it more difficult to develop and maintain recreational trails that cross private forest land.

"It becomes more and more difficult to pursue development of recreational trails because so many landowners become involved."

A second theme is that parcelization increases the cost of managing public forest land. The following are examples of this sentiment.

"As a public land manager, I deal with 100s of miles of property lines and disputes that arise because of them." 
"Parcelization often threatens access to public forest lands for recreation and timber management needs. There tends to be a lot more "gating" of forest accesses."

"Access issues are going to be a major problem to our agency."

The lack of management activity on small ownership tracts for timber and wildlife is also cited as an adverse outcome of parcelization. Consider the following observations offered by several respondents:

"It seems like the smaller the parcel a landowner has, the less likely they have interest in managing their land and less likely they are interested in education in land management."

"Forested parcels less than 20-40 acres become very difficult to manage for timber. Five acre zoning ordinances per 40 take the parcels out of production."

"The costs associated with moving from job to job for loggers is usually a somewhat fixed cost therefore making smaller and smaller parcels less financially feasible for contractors. Additionally, many new landowners of these smaller parcels are not open to the idea of managing their "piece of the wilderness'."

“As a former timber buyer, parcels less than 20 acres don't even get looked at as a source of timber."

A fourth theme regarding parcelization outcomes that emerged from the data is its impact on public infrastructure and service costs. The following comments illustrate this point.

"It currently seems that it is very typical for local officials and both local and state elected officials to believe that parcelization is good because they believe that parcelization = development $=$ higher taxes $=$ more funds for local units of government to operate. They often neglect to pay attention to the significant increase in costs for providing services to newly 
developed areas (often a much higher cost than the amount that they may see due to increased taxes)."

"Many people think their counties should sell land to increase the tax revenue. Citizens do not realize the cost to maintain roads for these new parcels of land."

"Each year that goes by I am more saddened than the next to see so many roads punched into the forest. When these roads are to access some privately owned riparian area, the feeling is worse in my guts."

"Make private landowners pay the real cost of their development, don't make the general taxpayer subsidize/cost share their parcelization such as the building/maintenance/snow plowing etc. and utilities new roads into the forest."

Yet not all survey respondents suggest that only adverse outcomes occur when private forest land is parcelized. The following comments suggest that parcelization is not having any impacts and/or is producing beneficial outcomes.

"In many cases, we actually observed better land management for early successional habitat through parcelization."

"In many cases the management will be better in private hands than the mills if our private land assistance programs are effectively carried out."

"I also don't think that just because an area is divided up that negative impacts necessarily occur."

\subsection{Strategies for Addressing Parcelization}

A number of public policy tools may be able to help mitigate the effects of forest land parcelization (Table 9). Given their role in implementing many of these, we asked public natural resource managers 
to comment on the effectiveness of seven such policy tools (5=very effective, $1=$ not effective).

Respondents rank conservation easements and preferential property tax programs as the two most effective tools $\left(1^{\text {st }}\right.$ and $2^{\text {nd }}$ respectively, median=4) for dealing with private forest land parcelization. Yet providing information on the potential adverse outcomes that can be associated with forest land parcelization was ranked least effective (median=2). Interestingly, providing land management assistance to landowners is viewed more effective than assisting landowners in estate planning.

A few respondents offered their perspective on the extent to which parcelization can be effectively addressed through public policy. The following are examples of these comments.

"I think to truly address this behavior it should be addressed through conservation easements and long term planning and zoning."

"The most effective way to deter parcelization - and least palatable to the public is zoning. We have a township that prohibits developing class 1,2, or 3 ag land. The difference in looking at the plat book pages for this versus other townships is dramatic."

"As land ownership falls into more and more hands, I think educating individuals of proper forestry/wildlife practices will become more and more critical."

"It is happening, occurring, etc, but currently none of our cost shared practices are directly presented to help prevent parcelization."

"The biggest driver of parcelization is people wanting to own their own piece of land where no one can tell them what to do. No amount of government programs is going to stop that from happening."

The survey asked public natural resource managers about their employer's ability to influence forest land parcelization activity (Table 10). Overall, respondents believe their agency has limited influence 
over parcelization ( $5=$ great ability, $1=$ no ability). Yet responses to this question vary, depending on whether the employer is a federal, state, or county/local agency $\left(\chi^{2}=13.16, p=0.001\right)$. Respondents working for state government feel their agency has more influence on parcelization activity than those employed by federal or county/local governments.

\section{DISCUSSION}

The goal of the study was to develop an in-depth characterization of how field-based public natural resource professionals in the Lake States view various aspects of forest parcelization. The study's qualitative and quantitative data collectively represents the most complete description of natural resource professionals' awareness of and attitudes and concerns towards forest parcelization to date.

Lake States natural resource managers view the parcelization of private forest land to be an important concern in the region. Our finding that more than $80 \%$ of respondents felt parcelization is a growing concern aligns with the findings of others (e.g., Gobster and Rickenbach 2004, Knoot et al. 2009) who also found that forest parcelization activity was increasing. We were unable to find any studies that concluded through empirical analysis or surveys of stakeholders that the rate of private forest land parcelization was decreasing.

Lake State public land managers' perceptions of what drives private forest land parcelization are generally consistent with findings from other studies. For example, our respondents' perceptions that forest land's potential for home development, proximity to population centers, and parcel amenity features (e.g., water frontage) are some of the most influential causes of parcelization have also been cited in other studies as influential factors (e.g., Germain et al. 2007, Haines et al. 2010). Drivers considered by our respondents to exert minimal influence on forest parcelization, such as timber harvesting and market, were also found to be inconsequential by others (e.g., Mehmood and Zhang 
2001). However, our study participants' belief that high property taxes contribute to forest parcelization is in contrast with an empirical analysis by Kilgore (2014) that found no correlation between high property taxes and forest land sale frequency.

While previous research has described impacts associated with private forest land parcelization (e.g., Mehmood and Zhang 2001, Gustafson and Loehle 2006, Mundell et al. 2010), our study identified a broader suite of impacts associated with forest land parcelization. In particular, the respondents stressed the important linkages between private forest land parcelization and public land management issues. This is in line with what we expected, even though empirical work on this topic is very limited. The only other work to address this issue (Rickenbach and Gobster 2003) also concluded that parcelization has increased pressure on public land, primarily as it relates to access for public recreation. While parcelization may be thought of as a uniquely private forest land issue and beyond the purview of public land managers, the implications appear to be far-reaching and requiring the attention of public land management agencies. Many of the parcelization outcomes listed in Table 8, while occurring on private land, impact public land management directly. For example, some respondents believe private forest land parcelization will make it more difficult to establish and maintain cross-boundary recreational trails and right-of-way access on neighboring public lands due to having a greater number of landowners to negotiate with. If true, agencies may find themselves having to devote greater amounts of resources and time in order to foster relationships and develop access arrangements with private landowners.

Other potential impacts of parcelization such as decreased timber supply and loss of recreational access on private forest land will, in all likelihood, impact the demand for these services on public forest land. Parcelization may also impact the success of public land managers to reduce fire risk or invasive species if surrounding lands are owned by a greater number of owners who may not be interested in or aware of the need to undertake landscape-scale approaches to risk reduction. Such 
impacts may necessitate greater effort and resources on the part of resource managers to educate and assist them in undertaking management activities that reinforce efforts being made on public lands. Additional research on many of these topics is needed to fully describe the issues and potential response strategies.

Natural resource managers working in state government felt their agency had more influence on parcelization, relative to those working for federal and local agencies. This sentiment may reflect the contact state agency personnel (e.g., assistance foresters) have with private forest landowners through the preparation of forest management plans and being the point of contact for landowner assistance (technical, financial) programs. It may also reflect the view of respondents that state government can most effectively develop policy and programs to address parcelization.

Our study suggests public land management agency employees do not believe they have the tools or ability to prevent parcelization from occurring. They indicate that current policies and incentive programs intended to prevent or manage the impacts of parcelization are having limited effect. Parcelization is, after all, a private decision that is influenced by a number of economic and social factors. Respondents rate private land management assistance more effective in mitigating parcelization than estate planning, which may reflect the traditional types of assistance many natural resource managers have been trained to deliver to private forest landowners. Moreover, it may be rooted in a perception that public agencies have little sway in preventing parcelization activities, but play a key role in fostering sound forest management in the face of parcelization. Mehmood and Zhang (2001) also found that landowner assistance programs can restrict parcelization activity. The open-ended comments provided by respondents also reveal that some believe zoning may be an effective, or even necessary, way to limit parcelization events. Yet this perception is not universal, as Rickenbach and Gobster (2003) found that some believe zoning policies may be unintentional drivers of parcelization and development. 
Given our findings, we suggest that land management agencies should not overlook the importance of education and incentive programs targeted at small parcel holdings to help these owners understand the important, collective role their forests play in providing ecosystem services. Additionally, agencies may want to target their information and assistance efforts to landowners that surround public lands as it is the decisions of these proximate landowners that may have the greatest and most immediate impact on public land resources. Such efforts could also help these landowners understand the benefits of cross-boundary cooperation between private landowners and public land management agencies. Public agencies might also consider shifting more resources toward acquiring easements and fee-simple acquisition of lands proximate to public lands to buffer against the spill-over effects of private-land parcelization and to help prevent public lands from becoming islands embedded within a developed landscape matrix.

Some respondents place parcelization in the context of other land use changes they see occurring within their work area. Specifically, they point out that as long as forest cover is maintained, the loss of forest function for timber, wildlife, and other ecosystem services that could ensue as a result of parcelization can be manageable. This perspective underscores the importance of maintaining forests as forests. It also points to the role that active management of private forests can play in addressing parcelization. For example, the two measure of forest management we evaluated, stumpage prices and timber harvesting activity, are considered by natural resource managers to be the two least influential drivers of parcelization. Moreover, the respondents to our survey indicate that land management assistance can be an effective strategy for mitigating parcelization. Together, these findings underscore the importance of policies and programs that encourage active management of private forests as a means minimizing or avoiding parcelization or potential impacts associated with parcelization. Such programs, policies, and assistance, however, may need to increasingly emphasize or be geared towards smaller landholdings. Thus, foresters, loggers, and extension agents should continue to explore ways to promote active forest management on smaller private forest land holdings, 
and in ways that resonate with landowners who own their forest land for primarily amenity and recreation reasons. While estate planning is and will continue to be an important tool in efforts to maintain private forest lands, we as natural resource professionals must also be prepared for the reality that parcelization events will continue to occur.

The study findings also highlight the need to better understand the relationship between parcelization and fragmentation, as others (e.g., Mundell et al. 2010, Haines et al. 2011) have found that forest parcelization can be a precursor to development. Whether parcelization leads to forest fragmentation is an empirical question. Additional research is needed to further describe and quantify the relationship between parcelization and fragmentation across a range of forest landscapes. Our research suggests that natural resource professionals have concerns about not only parcelization and the difficulties that may ensue with having to deal with a greater number of landowners, but also forest land development and fragmentation that may follow from parcelization.

Forest land parcelization will likely continue to occur in amenity-rich forested areas like the Lakes States. It will also, in all likelihood, create spillover effects on public forests. Public land management agencies need to be aware of these public land implications and, to the extent they occur, develop strategies for how to effectively deal with them. In this regard, the information from this study may be useful to public land management agencies in raising their awareness of the nature and degree of impact that may ensue from private forest land parcelization. Such awareness should assist them in preparing for and responding to the constraints and costs to public lands that may ensue.

\section{ACKNOWLEDGEMENTS}


The authors wish to thank the public natural resource managers who participated in this study.

Funding for this research was provided by the USDA Forest Service, Northern Research Station and the University of Minnesota's Agricultural Experiment Station (project 42-054).

\section{LITERATURE CITED}

Butler, B.J. 2008. Family forest owners of the United States, 2006. Gen. Tech. Rep. NRS-27. Newtown Square, PA: U.S. Department of Agriculture, Forest Service, Northern Research Station. $72 \mathrm{p}$.

Butler, B.J. and Z. Ma. 2011. Family forest owner trends in the northern United States. Northern Journal of Applied Forestry 28(1) 13-18.

Dillman, D.A., J.D. Smyth, and L.M. Christian. Internet, mail, and mixed-mode surveys: the tailored design method, $3^{\text {rd }}$ Edition. New Jersey: Jon Wiley and Sons, Inc. 2009.

Germain, R.H., N. Anderson, and E. Bevilacqua. 2007. Transfers on nonindustrial private forestland forest stocking in New York. Journal of Forestry 105(8): 403-408.

Gobster, P.H., and M.G. Rickenbach. 2004. Private forestland parcelization and development in Wisconsin's Northwoods: perceptions of resource-oriented stakeholders. Landscape and Urban Planning. 69:165-182.

Gustafson, E.J., and C. Loehle. 2006. Effects of parcelization and land divestiture on forest sustainability in simulated forest landscapes. Forest Ecology and Management 236(2-3): 305-314.

Haines, A.L., T.T. Kennedy, D.L. McFarlane. 2011. Parcelization: Forest change agent in northern Wisconsin. Journal of Forestry. 109(2): 101-107. 
Harrison, S., J. Herbohn, and A. Niskanen. 2002. Nonindustrial, smallholders, small-scale and family forestry: what's in a name? Small-Scale Forest Economics, Management and Policy 1(1): 1-11.

Hatcher, Jr., J.E., Straka, T.J., and J.L. Greene. 2013. The size of forest holding/parcelization problem in Forestry: A Literature Review. Resources 2: 39-57.

Kilgore, M.A., MacKay, D.G. 2007. Trends in Minnesota's forest land real estate market: implications for forest management. Northern Journal of Applied Forestry. 24(1):37-42.

Kilgore, M.A., S.A. Snyder, K. Block-Torgerson, and S.J. Taff. 2013. Challenges in characterizing a parcelized forest landscape: why metric, scale, and threshold matter. Landscape and Urban Planning 110(2013): 36-47.

King, S.L., Butler, B.J. 2005. Generating a forest parcelization map for Madison County, NY. In: Bevers, M., Barrett, T.M. (Eds.), Systems Analysis in Forest Resources: Proceedings of the 2003 Symposium, General Technical Report PNW-GTR-656. USDA Forest Service, Pacific Northwest Research Station, Portland, OR, pp 147-155.

Kittredge, D.B., D.B. Mauri, M.J. McGuire, J. Edward. 1996. Decreasing woodlot size and the future of timber sales in Massachusetts: When is an operation too small? Northern Journal of Applied Forestry 13(2): 96-101.

Knoot, T.G., L.A. Schulte, N. Grudens-Schunk, and M. Rickenbach. 2009. The changing social landscape in the Midwest: A boon for forestry and bust for oak? Journal of Forestry 107(5) 260266.

LaPierre, S., and R.H. Germain. 2005. Forestland parcelization in the New York City watershed. Journal of Forestry 103: 139-145. 
Leppanen, J. 2008. Parcelisation of family forests in Finland. P. 361-377 in: Biennial Meeting of the Scandinavian Society of Forest Economics, Lon, Norway, April 6-9, 2008.

Moldenhauer, M.C. and M.C. Bolding. 2009. Parcelization of South Carolina's private forestland: Loggers' reactions to a growing threat. Forest Products Journal 59(6): 37-43.

Mehmood, V.C., and D. Zhang. 2001. Forest parcelization in the United States: a study of contributing factors. Journal of Forestry 99(4): 30-34.

Mundell, J., S. Taff, M. Kilgore, and S. Snyder. 2010. Using real estate records to assess forest land parcelization and development: a Minnesota case study. Landscape and Urban Planning 94 (2010) 71-76.

National Association of State Foresters. 2015. Forest health, resiliency, and sustainability. Available online at: http://www.stateforesters.org/about-action-plans/forest-trends/forest-health-resiliencyand-sustainability; last accessed April 4, 2016.

Rickenbach, M.G., Gobster, P.H. 2003. Stakeholders' perceptions of parcelization in Wisconsin's northwoods. Journal of Forestry. 101(6), 18-23.

Sanborn-Stone, R. and M.L. Tyrrell. 2012. Motivations for family forestland parcelization in the Catskill/Delaware Watersheds of New York. Journal of Forestry 110(5): 267-274.

Society of American Foresters. 2015. Loss of U.S. private forestland: a position statement of the Society of American Foresters. Available online at: http://www.eforester.org/documents2016/Loss-of-US-Private-Forestland.pdf; last accessed April 4, 2016. 
Xie, Y., Gong, P., Han, Z., and Y. Wen. 2014. The effect of collective forestland tenure reform in China: Does land parcelization reduce forest management intensity. Journal of Forest Economics 20(2):126-140. 
Table 1. Survey recipients and usable responses, respectively, by unit of government and state. ${ }^{1}$

\begin{tabular}{|l|c|c|c|c|}
\hline & Federal & State & County/Local & TOTAL \\
\hline MI & $59 \mid 17$ & $108 \mid 27$ & $28 \mid 10$ & $195 \mid 54$ \\
\hline MN & $79 \mid 28$ & $153 \mid 61$ & $64 \mid 30$ & $296 \mid 119$ \\
\hline WI & $102 \mid 25$ & $144 \mid 56$ & $36 \mid 11$ & $282 \mid 92$ \\
\hline TOTAL & $240 \mid 70$ & $405 \mid 144$ & $128 \mid 51$ & $773 \mid 265$ \\
\hline
\end{tabular}

${ }^{1}$ State and/or employer information was not provided by 10 respondents. 
Table 2. Survey respondents by resource discipline and state. ${ }^{1}$

\begin{tabular}{|l|c|c|c|c|c|}
\hline & \multirow{2}{*}{ Forestry } & Wildlife & Soil \& Water & Planning & TOTAL \\
\hline MI & 28 & 10 & 10 & 6 & 54 \\
\hline MN & 82 & 19 & 4 & 15 & 120 \\
\hline WI & 49 & 17 & 24 & 3 & 93 \\
\hline TOTAL & 159 & 46 & 38 & 24 & 267 \\
\hline
\end{tabular}

${ }^{1}$ State and/or resource discipline was not provided by 8 respondents. 
Table 3. Familiarity with the concept of forest land parcelization. ${ }^{1}$ Percent of total in parenthesis.

\begin{tabular}{|c|c|c|c|c|c|c|c|c|c|c|c|}
\hline $\begin{array}{c}\text { Degree of } \\
\text { Familiarity }\end{array}$ & Federal $^{\mathrm{b}}$ & State $^{a}$ & $\begin{array}{l}\text { County } \\
\text { Local }^{\mathrm{a}}\end{array}$ & Forestry $^{\mathrm{a}}$ & Wildlife $^{\mathrm{ab}}$ & $\begin{array}{l}\text { Soil \& } \\
\text { Water }^{\mathrm{b}}\end{array}$ & $\begin{array}{c}\text { Recreation/ } \\
\text { Planning }^{\text {ab }}\end{array}$ & $\mathrm{MI}^{\mathrm{a}}$ & $\mathrm{MN}^{\mathrm{a}}$ & $\mathrm{WI}^{\mathrm{a}}$ & $\begin{array}{l}\text { Lake } \\
\text { States }\end{array}$ \\
\hline (not familiar) 1 & $8(11)$ & $1(1)$ & $1(2)$ & $2(1)$ & $1(2)$ & $5(13)$ & $2(8)$ & $1(2)$ & $4(3)$ & $5(5)$ & $11(4)$ \\
\hline 2 & $6(9)$ & $5(3)$ & $0(0)$ & $1(<1)$ & $4(9)$ & $4(11)$ & $2(8)$ & $3(6)$ & $2(2)$ & $6(6)$ & $11(4)$ \\
\hline 3 & $11(16)$ & $24(16)$ & $9(18)$ & $29(18)$ & $6(13)$ & $5(13)$ & $4(17)$ & $11(21)$ & $23(19)$ & $10(11)$ & $45(16)$ \\
\hline 4 & $31(44)$ & $41(28)$ & $11(22)$ & $45(28)$ & $16(35)$ & $18(47)$ & $6(25)$ & $15(28)$ & $42(35)$ & $28(30)$ & $87(32)$ \\
\hline (very familiar) 5 & $14(20)$ & $75(52)$ & $29(58)$ & $83(52)$ & $19(41)$ & $6(16)$ & $10(42)$ & $23(43)$ & $49(41)$ & $44(47)$ & $120(44)$ \\
\hline Median & 4.0 & 5.0 & 5.0 & 5.0 & 4.0 & 4.0 & 4.0 & 4.0 & 4.0 & 4.0 & 4.0 \\
\hline
\end{tabular}

${ }^{1}$ Units of government and disciplines with the same letter are not significantly different at $\alpha=0.05$. 
Table 4. Respondent concern about forest land parcelization. ${ }^{1}$ Percent of total in parenthesis.

\begin{tabular}{|c|c|c|c|c|c|c|c|c|c|c|c|}
\hline Degree of Concern & Federal $^{\mathrm{a}}$ & State $^{\mathrm{a}}$ & $\begin{array}{l}\text { County } \\
\text { /Local }^{\mathrm{a}}\end{array}$ & Forestry $^{\mathrm{a}}$ & Wildlife $^{\mathrm{a}}$ & $\begin{array}{l}\text { Soil \& } \\
\text { Water }^{\mathrm{a}}\end{array}$ & $\begin{array}{c}\text { Recreation/ } \\
\text { Planning }^{\mathrm{a}}\end{array}$ & $\mathrm{MI}^{\mathrm{a}}$ & $\mathrm{MN}^{\mathrm{a}}$ & $\mathrm{WI}^{\mathrm{a}}$ & $\begin{array}{c}\text { Lake } \\
\text { States }\end{array}$ \\
\hline (not a concern) 1 & $2(3)$ & $0(0)$ & $0(0)$ & $1(<1)$ & $0(0)$ & $0(0)$ & $1(4)$ & $2(2)$ & $0(0)$ & $0(0)$ & $2(<1)$ \\
\hline 2 & $2(3)$ & $1(<1)$ & $2(4)$ & $3(2)$ & $0(0)$ & $1(3)$ & $1(4)$ & $4(3)$ & $0(0)$ & $1(2)$ & $5(2)$ \\
\hline 3 & $17(24)$ & $19(13)$ & $5(10)$ & $22(14)$ & $6(13)$ & $9(24)$ & $4(16)$ & $17(14)$ & $19(20)$ & $5(9)$ & $41(15)$ \\
\hline 4 & $28(40)$ & $63(43)$ & $23(46)$ & $69(43)$ & $22(49)$ & $15(39)$ & $9(38)$ & $52(44)$ & $35(38)$ & $28(53)$ & $115(43)$ \\
\hline (important concern) 5 & $21(30)$ & $62(43)$ & $20(40)$ & $65(41)$ & $17(38)$ & $13(34)$ & $9(38)$ & $44(37)$ & $39(42)$ & $19(36)$ & $105(39)$ \\
\hline Median & 4.0 & 4.0 & 4.0 & 4.0 & 4.0 & 4.0 & 4.0 & 4.0 & 4.0 & 4.0 & 4.0 \\
\hline
\end{tabular}

${ }^{1}$ Units of government and disciplines with the same letter are not significantly different at $\alpha=0.05$. 
Table 5. Respondent's characterization of employer's concern about forest land parcelization. ${ }^{1}$ Percent of total in parenthesis.

\begin{tabular}{|r|r|r|r|r|}
\hline Degree of Concern & \multicolumn{1}{|c|}{ Federal $^{\mathrm{b}}$} & State $^{\mathrm{a}}$ & County/Local $^{\mathrm{ab}}$ & Lake States \\
\hline (not a concern) 1 & $12(17)$ & $4(3)$ & $5(10)$ & $21(8)$ \\
\hline 3 & $16(23)$ & $10(7)$ & $11(22)$ & $37(14)$ \\
\hline 4 & $11(16)$ & $62(43)$ & $12(25)$ & $85(32)$ \\
\hline (important concern) 5 & $7(10)$ & $24(16)$ & $10(20)$ & $41(16)$ \\
\hline Median & 3.0 & 4.0 & 3.0 & 3.0 \\
\hline
\end{tabular}

Government levels with the same letter are not significantly different at $\alpha=0.05$. 
Table 6. Characterization of change in forest land parcelization in the respondent's work area over the last 10 years. ${ }^{1}$ Percent of total in parenthesis.

\begin{tabular}{|r|r|r|r|r|}
\hline Change in Parcelization & $\mathrm{MI}^{\mathrm{b}}$ & $\mathrm{MN}^{\mathrm{a}}$ & $\mathrm{WI}^{\mathrm{a}}$ & Lake States \\
\hline (decreased substantially) 1 & $1(2)$ & $0(0)$ & $0(0)$ & $1(<1)$ \\
\hline 2 & $2(4)$ & $3(3)$ & $2(2)$ & $7(3)$ \\
\hline (no change) 3 & $7(13)$ & $21(20)$ & $6(7)$ & $34(14)$ \\
\hline 4 & $38(72)$ & $51(49)$ & $49(59)$ & $138(57)$ \\
\hline (increased substantially) 5 & $5(9)$ & $30(29)$ & $26(31)$ & $61(25)$ \\
\hline Median & 4.0 & 4.0 & 4.0 & 4.0 \\
\hline
\end{tabular}

States with the same letter are not significantly different at $\alpha=0.05$. 
Table 7. Perceived drivers of forest land parcelization $(1=$ not influential, $5=$ very influential $)$.

\begin{tabular}{|c|c|c|c|c|c|c|c|c|c|c|c|}
\hline & $\begin{array}{c}\text { Home } \\
\text { Develop- } \\
\text { ment } \\
\text { Potential }\end{array}$ & $\begin{array}{l}\text { Proximity to } \\
\text { Population } \\
\text { Centers }\end{array}$ & $\begin{array}{c}\text { Parcel } \\
\text { Features }\end{array}$ & $\begin{array}{l}\text { Land } \\
\text { Prices }\end{array}$ & $\begin{array}{c}\text { Inter- } \\
\text { generational } \\
\text { Ownership } \\
\text { Transfer }\end{array}$ & $\begin{array}{c}\text { Property } \\
\text { Taxes }\end{array}$ & $\begin{array}{l}\text { Real Estate } \\
\text { Speculation }\end{array}$ & $\begin{array}{l}\text { Proximity } \\
\text { to Public } \\
\text { Land }\end{array}$ & $\begin{array}{c}\text { Commercial } \\
\text { Development } \\
\text { Potential }\end{array}$ & $\begin{array}{c}\text { Stumpage } \\
\text { Prices }\end{array}$ & $\begin{array}{c}\text { Timber } \\
\text { Harvesting }\end{array}$ \\
\hline Median & 4.0 & 4.0 & 4.0 & 4.0 & 4.0 & 4.0 & 3.0 & 3.0 & 3.0 & 2.0 & 2.0 \\
\hline $\begin{array}{l}\text { Rank } \\
\text { Sum }^{1}\end{array}$ & 858 & 832 & 818 & 816 & 765 & 759 & 715 & 691 & 633 & 539 & 515 \\
\hline
\end{tabular}

${ }^{1}$ Sum of individual ratings across all respondents. 
Table 8. Perceived outcomes of forest land parcelization $(1=$ not likely to occur, $5=$ very likely to occur).

\begin{tabular}{|c|c|c|c|c|c|c|c|c|c|c|c|c|c|}
\hline & $\begin{array}{l}\text { Increased } \\
\text { Land } \\
\text { Develop } \\
\text { ment }\end{array}$ & $\begin{array}{c}\text { Decreased } \\
\text { Private } \\
\text { Land } \\
\text { Timber } \\
\text { Supply }\end{array}$ & $\begin{array}{l}\text { Loss of } \\
\text { Private } \\
\text { Land } \\
\text { Rec } \\
\text { Access }\end{array}$ & $\begin{array}{l}\text { Increased } \\
\text { Demand } \\
\text { on Public } \\
\text { Land }\end{array}$ & $\begin{array}{l}\text { Loss of } \\
\text { Wildlife } \\
\text { Habitat }\end{array}$ & $\begin{array}{l}\text { Increased } \\
\text { Cost of } \\
\text { Govt. } \\
\text { Services }\end{array}$ & $\begin{array}{l}\text { Increased } \\
\text { Conflict } \\
\text { on Public } \\
\text { Land }\end{array}$ & $\begin{array}{c}\text { Loss of } \\
\text { Rural } \\
\text { Character }\end{array}$ & $\begin{array}{l}\text { Increase } \\
\text { d Road } \\
\text { Density }\end{array}$ & $\begin{array}{l}\text { Loss of } \\
\text { Public } \\
\text { Land } \\
\text { Access }\end{array}$ & $\begin{array}{c}\text { Increased } \\
\text { Public } \\
\text { Land Mgmt } \\
\text { Costs }\end{array}$ & $\begin{array}{l}\text { Increased } \\
\text { damage to } \\
\text { Public } \\
\text { Land }\end{array}$ & $\begin{array}{l}\text { Loss of } \\
\text { Private } \\
\text { Forest } \\
\text { Land }\end{array}$ \\
\hline Median & 5.0 & 5.0 & 5.0 & 4.0 & 4.0 & 4.0 & 4.0 & 4.0 & 4.0 & 4.0 & 4.0 & 4.0 & 3.0 \\
\hline $\begin{array}{l}\text { Rank } \\
\text { Sum }^{1}\end{array}$ & 996 & 983 & 964 & 936 & 870 & 902 & 895 & 880 & 865 & 783 & 778 & 785 & 753 \\
\hline
\end{tabular}

${ }^{1}$ Sum of individual ratings across all respondents. 
Table 9. Perceived effectiveness of policy tools in mitigating forest land parcelization impacts $(1=$ not effective, 5 = very effective).

\begin{tabular}{|c|c|c|c|c|c|c|c|}
\hline & & Property & Land & Land & Estate & Better & Landowners on \\
& Conservation & Tax & Use & Management & Planning & Timber & Parcelization \\
& Easements & Programs & Zoning & Assistance & Assistance & Markets & Impacts \\
\hline Median & 4.0 & 4.0 & 3.5 & 3.0 & 3.0 & 3.0 & 2.0 \\
\hline Rank & 775 & 704 & 681 & 624 & 588 & 588 & 488 \\
\hline
\end{tabular}


Table 10. Perceived ability of employer to influence forest land parcelization activity. ${ }^{1}$ Percent of total in parenthesis.

\begin{tabular}{|c|c|c|c|c|}
\hline & Federal $^{b}$ & State $^{\mathrm{a}}$ & County/Local $^{\mathrm{b}}$ & Lake States \\
\hline (no ability) 1 & $17(25)$ & $8(6)$ & $15(28)$ & $40(15)$ \\
\hline 2 & $24(35)$ & $51(35)$ & $15(28)$ & $90(34)$ \\
\hline 3 & $16(23)$ & $44(31)$ & $10(19)$ & $70(26)$ \\
\hline 4 & $10(15)$ & $31(22)$ & $10(19)$ & $51(19)$ \\
\hline (great ability) 5 & $2(3)$ & $10(7)$ & $3(6)$ & $15(6)$ \\
\hline Median & 2 & 3 & 2 & 3 \\
\hline
\end{tabular}

${ }^{1}$ Government levels with the same letter are not significantly different at $\alpha=0.05$. 